\title{
Management and Investigation of Drug Utilization Case behind the Death of Bollywood Actor Sushant Singh Rajput
}

\author{
Dr. Rajdeep Deb ${ }^{1} \mid$ Dr. Shekhar Kapoor ${ }^{2} \mid$ Dr. Tripti Yadav ${ }^{3} \mid$ Dr. Ruchi Sharma ${ }^{4}$
}

\begin{abstract}
${ }^{1}$ Associate Professor, School of Entrepreneurship Skills, Bhartiya Skills Development University, Jaipur, Rajasthan ${ }^{2}$ Asst. Professor, School of Entrepreneurship Skills, Bhartiya Skills Development University Jaipur, Rajasthan ${ }^{3}$ Asst. Prof. Dept. of Botany, SS Jain Subodh College of Global Excellence, Sitapura, Jaipur ${ }^{4}$ Asst. Professor of Botany, Vivek PG College, Kalwar, Jaipur
\end{abstract}

\section{To Cite this Article}

Dr. Rajdeep Deb, Dr. Shekhar Kapoor, Dr. Tripti Yadav and Dr. Ruchi Sharma, "Management and Investigation of Drug Utilization Case behind the Death of Bollywood Actor Sushant Singh Rajput", International Journal for Modern Trends in Science and Technology, 6(9): 35-37, 2020.

\section{Article Info}

Received on 06-August-2020, Revised on 20-August-2020, Accepted on 25-August-2020, Published on 30-August-2020.

\section{ABSTRACT}

On 14 June 2020, Indian actor Sushant Singh Rajput was found dead hanging from the ceiling fan at his home in Bandra, Mumbai, with the cause ruled assuicide. The official postmortem reports concluded that he died of asphyxiadue to hanging. The Mumbai Police launched an investigation into the death, which was surrounded by rumours and speculation.

The Enforcement Directorate (ED) probing the money laundering angle in Bollywood actor Sushant Singh Rajput's death questioned Rhea Chakraborty's father for the second time for nearly six hours on Thursday. It was doubted that the actor took mendrex, metamiphine and other drugs to treat depression like opiates and morphine.

Officials summoned Indrajeet Chakraborty to the Axis Bank branch in Mumbai's Vakola and was asked to bring the keys to his family's bank lockers, people familiar with the developments told Hindustan Times. After he sought police protection, a Mumbai police constable escorted Rhea's father to the bank at around 2:30 pm. He returned home at $9.30 \mathrm{pm}$.

The central agency had earlier questioned Chakraborty, her father and her brother Showik on August 10. Chakraborty's manager Shruti Modi and Sushant Rajput's friend and roommate Siddharth Pithani have also been questioned by the ED.

Investigators had earlier gathered information about the formation of four companies by Rajput and Chakraborty, and her family. Two of these companies were registered while the other two were under the process of getting registered. They wanted to go through the Memorandum of Understanding (MoU) signed during the formation of these firms to find out the profit sharing agreement.

\section{INTRODUCTION}

People in the agency familiar with the development have said that Chakraborty had responded to all the questions but could not divulge details of the exact sequence of events. ED has also questioned Rajput's house manager 
Samuel Miranda, Chakraborty's chartered accountant Ritesh Shah, and Rajput's chartered accountant Sandeep Sridhar in the case.

Actor Rhea Chakraborty was on Friday questioned by the Central Bureau of Investigation (CBI) for the first time since it took over the probe into the death of Sushant Singh Rajput.

Chakraborty was summoned by the central agency to appear before its probe team on Friday around 10.30am. Chakraborty, Rajput's girlfriend, left her residence around 10am to reach the DRDO guest house in suburban Santacruz, where the probe team is stationed, news agency PTI reported.

Chakraborty reached the DRDO guesthouse in Mumbai's Santacruz East area along with her brother Shovik where she will be questioned by the central agency.[1]

Before Chakraborty's arrival, Rajput's friend and flatmate Siddharth Pithani and manager Samual Miranda had reached the DRDO guest house to join the investigation.

The CBI team, which is in the city since the last eight days to investigate the case, on Thursday recorded Shovik's statement for more than eight hours. Chakraborty's father has also been questioned by several investigators.

The CBI has so far questioned the late actor's flatmate Pithani, cook Neeraj Singh and domestic help Deepesh Sawant, among others, as part of its probe in the high-profile case.

The Supreme Court last week upheld the transfer of the first information report (FIR), lodged by Rajput's father in Bihar's Patna against Rhea Chakraborty and others for allegedly abetting his son's suicide and misappropriating his money, to the central agency.

Rajput was found dead at his Bandra home on June 14.

\section{DISCUSSION}

Author Chetan Bhagat has called for restraint on the media coverage of the Sushant Singh Rajput death case at a time when the country is facing big challenges, one of them the coronavirus crisis and the row over holding national entrance exams for engineering and medical courses.

"With all respect to Sushant, I loved him; I owe my career to him. Kai Po Che was not getting made. I was not getting a movie started after 3 Idiots because of whatever happened. Sushant saved me, so please, nobody can really say I don't care for him. But we have to care for India also. We cannot spend months and months making that (the case) the prime time issue," the author whose 2004 bookFive Point Someone became wildly popular among young people told NDTV. Mr Rajput was one of the lead actors in the 2013 film Kai Po Che.

"We wanted a different (probe) agency, we have got it. We have got the top agency, the top people. Now each and every time people want different clues to this puzzle, I don't think it's going to achieve anything," Mr Bhagat said.[2]

Mr Rajput, 34, was found dead in his Mumbai apartment on June 14. More than a month later, his father KK Singh filed a case in Bihar, accusing his friend Rhea Chakraborty and her family of cheating him financially and mentally harassing him, driving him to suicide.

Every country has problems with their economy. Every responsible country is trying to get out of it and we need to shift our focus back. It's very entertaining, this case, it has everything in it. Alleged murder, a suicide maybe, movie stars and all conspiracy theories and politics, but no matter how interesting it is, it is not a story. It is real life and you have to get evidence. Either you let the CBI do their job or say you don't need the CBI, you can solve the case yourself on TV tonight. Move on to the economy, the vaccine, how are we going to distribute the vaccine, how do we check phase 3 trials, the exams," Mr Bhagat told NDTV.

Mr Bhagat in a departure from his previous work has just written a thriller, One Arranged Murder.

The 'Kai Po Che' actor was found hanging at his residence in Bandra on June 14. Rhea Chakraborty has been accused of abetment to suicide and money laundering among other charges in an FIR filed by the late actor's father KK Singh. A petition has been filed by actor Rhea in the apex court seeking transfer of investigation in the case to Mumbai, said her lawyer Satish Maneshinde on July 29. Meanwhile, on Friday, she was questioned by the Enforcement Directorate (ED) at its office in Mumbai along with brother Showik Chakraborty, and Shruti Modi. Showik was also called by the agency on August 8 and was questioned for several hours. The late actor's friend Siddharth Pithani was also summoned but did not appear yesterday. He might be questioned on Monday, August 10 along with Rhea who has already been summoned by ED. 


\section{MORE INVESTIGATIONS}

The 'Jalebi' actress revealed the only two things of her late boyfriend Sushant Singh Rajput that she possesses. Rhea's lawyer Satish Maneshinde has shared a photo of a "gratitude list" written by Sushant on Rhea's notebook, where he has mentioned that he is grateful for his life and the presence of Rhea's family in his life. She also shared a photo the late actor's sipper with "Chhichhore" -- the title of Sushant's 2019 hit -written on it.

"The only property of Sushant that I possess. And this is his handwriting lillu is showik (her brother), bebu is me, sir is my dad, ma'am is my mom, fudge is his dog," Rhea explained the names on the note.[3]

Apart from the CBI and the Enforcement Directorate (ED), which is probing a money-laundering angle into Sushant's death, now the Narcotics Control Bureau (NCB) has also registered an FIR against Rhea and some others under several sections of the Narcotic Drugs and Psychotropic Substances (NDPS) Act.

The CBI took over the case from the Mumbai Police after the Supreme Court judgement in Sushant's girlfriend Rhea's plea to transfer the FIR in the case from Patna to Mumbai. Their team also visited Sushant's flat to reconstruct the sequence of events before he was found dead on June 14 .

A Zero FIR is registered in a police station that would have otherwise refused to register the FIR for lack of territorial jurisdiction. It is then transferred to the appropriate police station. However, the FIR registered by Bihar Police was a regular FIR and not a Zero FIR.

The objective of introducing the concept of Zero FIR was to ensure the question of territorial jurisdiction doesn't prove a hurdle in filing of FIRs in cases that require immediate action.

The same is reflected in Section 3 of the Criminal Amendment Act 2013, which focuses on the importance of lodging FIRs and does not discuss the issue of transferring.

The Ministry of Home Affairs issued a circular on 10 May 2013 (circular), stating that if, at the time of registration of the Zero FIR, it appears prima facie that the cause of action occurred wholly in another jurisdiction, the FIR should be transferred. However, the circular was only advisory in nature and not binding.

In light of Supreme Court judgments that disallow interference on the ground of territorial jurisdiction at the stage of investigation
- Satvinder Kaur v. State (Govt. of NCT Delhi), 1999, and Rasiklal Dalpatram Thakkar v. State of Gujarat, 2010 - it cannot be said that the circular places a specific duty on Bihar Police to transfer the FIR. Thus, the law, as laid by the Supreme Court, will take precedence over the circular. $[4,5]$

That apart, the Bihar government's recommendation for a $\mathrm{CBI}$ investigation has been accepted by the central government. Thus, the issue of transfer of the case from Bihar Police to Mumbai Police under the concept of Zero FIR does not arise.

\section{CASE STILL CONTINUES}

Further, the CBI requires the consent of the Maharashtra government to enter the state for exercising its powers and jurisdiction. If the state government refuses to give its consent, the Supreme Court has the power to order a CBI investigation.

Therefore, it has to be seen if the Maharashtra government agrees to the central government's directions or whether the issue of the CBI's jurisdiction will also be dragged to the Supreme Court for adjudication.

\section{REFERENCES}

[1] Shruti Shiksha (21 January 2018). "'Happy Birthday, Sushant Singh Rajput. Keep That Childlike Smile Always Alive,' Tweets Kriti Sanon". NDTV. Retrieved 6 December2018.

[2] "Did you know Sushant Singh Rajput had visited his birthplace in Bihar recently after 17 years?". The Times of India. 14 June 2020. Retrieved 12 July 2020.

[3] "Sushant Singh Rajput father faints". India TV. 14 June 2020. Retrieved 12 July 2020.

[4] "Sushant Singh Rajput dies by suicide at 34 in Mumbai". India Today. 14 June 2020. Retrieved 14 June2020.

[5] "Kedarnath actor Sushant Singh Rajput turns entrepreneur with Innsaei". The Indian Express. 18 May 2018. Retrieved 13 August 2018.; "Sushant Singh Rajput donates Rs 1 crore as aid for Kerala on behalf of a fan. Read details". Hindustan Times. 22 August 2018. Retrieved 14 September 2018.; "After Donating 1 Crore to Kerala, Sushant Singh Rajput Gives Rs 1.25 Crore for Nagaland Relief Fund". News18. Retrieved 14 September2018.; "Sushant Singh Rajput visits blind school in Ranchi, embraces kid after his singing act-Watch". Zee News. 22 August 2018. Retrieved 14 September 2018. 